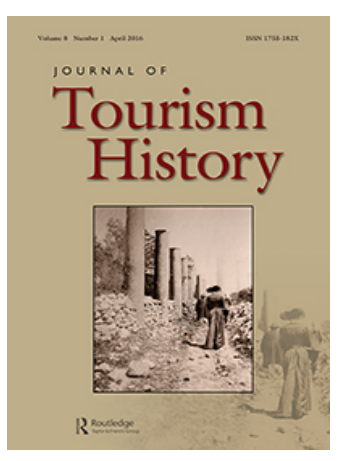

Journal of Tourism History

\title{
Empire in waves: a political history of surfing
}

\section{Brendan Hokowhitu}

To cite this article: Brendan Hokowhitu (2016) Empire in waves: a political history of surfing, Journal of Tourism History, 8:1, 92-93, DOI: 10.1080/1755182X.2016.1167871

To link to this article: http://dx.doi.org/10.1080/1755182X.2016.1167871

曲 Published online: 11 Apr 2016.

Submit your article to this journal

Џ Article views: 25

Q View related articles $\sqsubset$

View Crossmark data $₫$ 


\section{BOOK REVIEWS}

Empire in waves: a political history of surfing, by Scott Laderman, Berkley, Los Angeles and London, University of California Press, 2014, 238 pp., US\$65.00, $£ 44.95$ (cloth), ISBN 978-0-520-27910-0, US\$26.95, £18.95 (paperback), ISBN 978-0-520-27911-7

Scott Laderman's impressive Empire in Waves debunks the myths surrounding surfing that enable its apolitical mysticism and cachet. Most notable is the book's contextual breadth, its cross-disciplinarity and richness in research. The author's discursive account moves between history, cultural studies, political science and anthropology, whilst crossing international borders to places such as Indonesia, South Africa and Hawai'i. Laderman provides no better example of this than in his analysis of US foreign policy via the cult classic surf film Endless Summer by American filmmaker Bruce Brown. At face value, the movie represents the ceaseless and convivial search for the perfect wave yet, in light of the Cold War, it can also be seen as a tale of benevolent neo-colonialism and endless white privilege. As Laderman suggests, the resounding success of the film amongst non-surfer audiences and the fascination with surfing in general that is common among many non-participants has less to do with an attraction to the exotic, and more to do with the possibilities of neoimperial power and desire.

Beginning in chapter 1, Laderman convincingly unravels the colonial and racist desires in early-twentieth-century Hawai'i that gave rise to the surfboard as a vehicle to both fetishise the brown colonised body and to uphold the coloniser's civilising burden. He continues this project in chapter 2 by examining the depoliticisation of the neo-colonial will to 'find the perfect wave' in often Third-World locations where, 'Surfers began to sound a lot like anthropologists' (67). From the 1950s onwards, and fermented by a growing white middle-class travel culture, surfers promoted surfing as a lofty spiritual endeavour that transcended politics. In chapter 3, Laderman explores the ethics of surf travel to countries with atrocious humanrights records, including Indonesia, where surfers chose to ignore the unconscionable acquiescence of the US government in Suharto's holocaust in East Timor. He goes on to examine this theme in chapter 4 by looking at arguments for and against the continuance of the ASP World Tour events in Apartheid South Africa during the 1980s, where just a handful of influential surfers such as Tom Carroll, Martin Potter and Tom Curren refused to participate. The analysis here is particularly drawn out, focusing on a public dialogue in Surfer, an American magazine, which only served to remind me of the imbecilic nature of many of my surfing comrades who, not varying far from the Beavis and Butthead stereotype, are typically young, white privileged men, who tend to uncritically view the world in general. Instead, the discussion could have investigated how the apolitical apologist discourse married with other sports, such as rugby and cricket. It may be no coincidence, for instance, that the future world champion and South African boycotter, Tom Curren, first travelled to South Africa with the US amateur team in 1981, the year that the Springbok rugby team travelled to New Zealand amidst worldwide condemnation. The 'honourary white status' that surfers such as Derek Ho, Eddie Aikau and others were afforded has garnered a lot of attention by Black sport commentators who were both critical of 'coloured players' in visiting teams, and adulatory about the possibilities the spectacle that brown bodies competing against the oppressor signalled. Finally, in chapter 5, 
beginning in the 1970s, Laderman examines the surf industry's devolution from organic producer in Torquay, Australia to sweatshop manufacturer in the Third World, and demonstrates the corruptibility of 'surfing soul', where its edgy, spiritual, organic hipness was commodified through invented narratives attached to a multi-billion dollar and unethical clothing industry fostered by brands such as Quicksilver, Rip Curl, Billabong, Hurley (Nike), Patagonia and Hollister. As Laderman points out, the paradox here is the capitalist production of ' ... grossly unbalanced relationships with those same brown-skinned peoples that surfers have romanticised during their numerous global jaunts' (142).

Laderman does an excellent job of laying bare the ugliness of a particular surf culture, yet there is a certain amount of settler imperialism in what is left unsaid. Laderman is largely silent on the oppressive regimes of countries such as the US and Australia, particularly in relation to their Indigenous peoples. Whilst there is a focus on exotic locales such as Hawai' $i$ and Indonesia, and 'oppressive regimes' such as South Africa and China, little regard is given to the complicity of surfing with the colonialism that occurred in surfing hotspots such as California, Florida, Surfers' Paradise and Bondi, where beaches very much became the white hetero-patriarchal domain of the surfer, clubby and bather. By focusing on the apoliticism of surfing in juxtaposition to those few surfers who chose to boycott 'oppressive regimes' there was a tendency to both lionise these surfers, and single out countries such as South Africa and China. Yet, ironically, given the stature of Hawai'i in relation to surfing, nothing is made of the continued illegal occupation of Hawai'i by the US, nor the US and Australia's atrocious and ongoing subjugation of their Indigenous peoples' rights. Hence, very little is made of Tom Carroll's myopic comprehension of his own country's abuses that continued throughout the heyday of Australian surfing, including the exclusion of Australian Aboriginal and Torres Strait Islanders from voting rights until 1962, the Stolen Generation policy that continued into the 1970s and the suppression of native-land-title until the Mabo case in 1992. Thus, when Laderman asks, in relation to the emergence of Chinese surf contests, '[h]ow is it that a sport that reputedly embraced rebellion could so eagerly jump into bed with a regime responsible for widespread political repression?' (156); the answer is obvious: it is a product of regimes of oppression.

Empire in Waves, however, should not be judged solely on this bias, for it is also highly critical of surfing's relationship to white male power, unfettered exploration and hedonism. Laderman's general depiction suggests to me that surf culture replicates Dostoevsky's ubermenschian figure, Svidrigailov (Crime and Punishment), whose function in life is to satisfy his sensual desires whilst reproducing the evil of the world as a mere symptom of that world. That is, Empire in Waves suggests a nihilistic surf culture that seeks pleasurable gratification in the face of life's meaninglessness. The metaphysical dimension to surfing, Laderman argues, has enabled surfers to narrate a simple apolitical tale of adventurism, aestheticism and nature amongst oceans stained red, reminding us that corporeality and metaphysicality are conditioned by the power differential between free subjects. At least the unscrupled Svidrigailov did not justify or veil his vulgarity, as has been the tendency of surfers to do.

Brendan Hokowhitu

Te Pua Wānanga ki Te Ao, University of Waikato, Hamilton, Waikato, New Zealand @ hokowhitu@waikato.ac.nz 